\title{
TRPA1 promotes cisplatin-induced nephrotoxicity through inflammation mediated by the MAPK/NF- $K B$ signaling pathway
}

\author{
Jinyan Yuan ${ }^{1,2 \#}$, Xiao Liang ${ }^{3 \#}$, Wei Zhou ${ }^{2 \#}$, Jing Feng ${ }^{4}$, Zhenyang Wang ${ }^{1,2}$, Shaoxian Shen ${ }^{5}$, Xin Guan ${ }^{5}$, \\ Liangbin Zhao ${ }^{6}$, Fei Deng ${ }^{1,5}$
}

${ }^{1}$ Department of Nephrology, Sichuan Academy of Medical Sciences and Sichuan Provincial People's Hospital, University of Electronic Science and Technology of China, Chengdu, China; ${ }^{2}$ School of Medicine, University of Electronic Science and Technology of China, Chengdu, China; ${ }^{3}$ Department of Internal Medicine, Sichuan Academy of Medical Sciences and Sichuan Provincial People's Hospital, University of Electronic Science and Technology of China, Chengdu, China; ${ }^{4}$ Department of Traditional Chinese Medicine, Sichuan Academy of Medical Sciences and Sichuan Provincial People's Hospital, University of Electronic Science and Technology of China, Chengdu, China; ${ }^{5}$ Department of Nephrology, Jinniu Hospital of Sichuan Provincial People's Hospital and Chengdu Jinniu District People's Hospital, Chengdu, China; ${ }^{6}$ Department of Nephrology, Hospital of Chengdu University of Traditional Chinese Medicine, Chengdu, China

Contributions: (I) Conception and design: J Yuan, X Liang, L Zhao, F Deng; (II) Administrative support: W Zhou, L Zhao; (III) Provision of study materials or patients: J Yuan, X Liang, W Zhou, J Feng; (IV) Collection and assembly of data: Z Wang, S Shen, X Guan; (V) Data analysis and interpretation: J Yuan, X Liang, W Zhou; (VI) Manuscript writing: All authors; (VII) Final approval of manuscript: All authors.

\#These authors contributed equally to this work.

Correspondence to: Liangbin Zhao. Department of Nephrology, Hospital of Chengdu University of Traditional Chinese Medicine, 39 Shierqiao Road, Jinniu District, Chengdu 610072, China. Email: zhaoliangbin@cdutcm.edu.cn; Fei Deng. Department of Nephrology, Sichuan Academy of Medical Sciences and Sichuan Provincial People's Hospital, 32 W. Sec 2, 1st Ring Rd. (Qingyang Taoist Temple Diagonally Opposite), Chengdu 610072, China. Email: dengfei_here@163.com.

Background: The nephrotoxicity induced by cisplatin (DDP) has been a severe obstacle for its clinical use in anticancer treatment. The apoptosis and inflammation induced by DDP are the main causes of the nephrotoxicity. Transient receptor potential ankyrin 1 (TRPA1) is a non-selective cation ligand-gated channel that is involved in the inflammation progress.

Methods: The apoptosis, inflammation, MAPK/NF- $\kappa \mathrm{B}$ signaling pathway, and TRPA1 expression were assessed after HEK293 cells had been induced by DDP, and the role of TRPA1 in apoptosis and inflammation of DDP-induced HEK293 cells treated with TRPA1 antagonist HC-030031 was also evaluated by quantitative reverse transcription-polymerase chain reaction (qRT-PCR), flow cytometry, and western blot assays.

Results: The cell viability was reduced by DDP in both a time-dependent and dose-dependent manner with a minimal cytotoxic concentration of $10 \mu \mathrm{M}$. Moreover, DDP induced an enhancement of the apoptosis and inflammation in a dose-dependent manner, as indicated by the increase of the relative protein level of cleaved-caspase3 (cleaved-cas3), the cleavage product of caspase-3 substrate poly-ADP-ribose polymerase (cleaved-PARP) and inducible nitric oxide synthase (iNOS), and the messenger RNA (mRNA) expression level of interleukin $(I L)-1 \beta, I L-6$, tumor necrosis factor- $\alpha(T N F-\alpha)$, and interferon- $\gamma(I N F-\gamma)$. Additionally, DDP treatment increased the protein phosphorylation expression of IKK $\beta$, JNK, ERK, and p38 in a dosedependent manner, which was antagonized by the treatment of NF- $\kappa$ B-specific inhibitor BAY 11-7082 and pan-MAPK inhibitor U0126. It was also found that DDP upregulated the expression of TRPA1 at both the mRNA and protein levels in a dose-dependent manner. Besides, block of TRPA1 with HC-030031 relieved the apoptosis, diminished the level of $I L-1 \beta, I L-6, T N F-\alpha$, and $I N F-\gamma$, reduced the level of cleaved-cas3, cleaved-PARP, and iNOS, decreased the p-IKK $\beta$, p-JNK, p-ERK, and p-p38 expression, and enhanced the expression of $\mathrm{I} \kappa \mathrm{B} \alpha$.

Conclusions: Taken together, these results indicate that TRPA1 regulates DDP-induced nephrotoxicity via inflammation mediated by the MAPK/NF- $\mathrm{BB}$ signaling pathway in HEK293 cells. 
Keywords: Cisplatin (DDP); nephrotoxicity; transient receptor potential ankyrin 1 (TRPA1); apoptosis; MAPK/ $\mathrm{NF}-\kappa \mathrm{B}$ signaling pathway

Submitted Aug 17, 2021. Accepted for publication Oct 21, 2021.

doi: $10.21037 / \mathrm{atm}-21-5125$

View this article at: https://dx.doi.org/10.21037/atm-21-5125

\section{Introduction}

Cisplatin (DDP) is a leading chemotherapy drug in the treatment of a variety of malignant solid tumors (1-3), such as non-small cell lung carcinoma, ovarian, head and neck, testicular, cervical, and numerous other cancers (2-5). Although DDP has become a mainstay for cancer therapy, its side effects are also non-negligible in clinical practice, and its nephrotoxicity has been a particularly dominating obstacle that restricts the use and efficacy of DDP in tumor therapy (4,6-10). Currently, about one-third of patients have been shown to experience nephrotoxicity with DDP treatment $(4,11)$, among which acute kidney injury (AKI) is the most common and serious manifestation of nephrotoxicity (12). Renal apoptosis (13) and inflammation (14) have been recognized as the most important mechanism underlying DDP-induced nephrotoxicity.

The nephrotoxicity induced by DDP principally exists in proximal tubule epithelial cells (15). A vital factor underlying DDP-induced cellular apoptosis and inflammation is the massive production of oxygen free radicals. Atessahin et al. (16) showed that DDP-treated male rats have singlet oxygen, and other study also found that DDP can cause the increase of $\mathrm{O}_{2}$ of renal cells in male rats (17). The lack of antioxidant protection also plays an important role in DDP-induced cellular apoptosis and inflammation. The most effective cellular antioxidant system is the glutathione (GSH) oxidation cycle. As it passes through tubule epithelial cells, DDP depletes the level of endogenous oxide scavenger GSH, which leads to the imbalance of intracellular oxidation and accumulation of reactive oxygen species (ROS) to induce a series of stress responses $(18,19)$. The ROS can activate a signaling cascade, such as the MAPK (20) and NF- $\kappa B$ (21) signal pathway, which triggers the production and release of numerous pro-inflammatory cytokines, such as interleukin $(I L)-1 \beta, I L-6$, tumor necrosis factor- $\alpha(T N F-\alpha)$, and interferon- $\gamma(I N F-\gamma)(22)$, as well as the inflammatory mediator inducible nitric oxide synthase (iNOS) (23). Consequently, the production and release of the pro-inflammatory cytokines and inflammatory mediator cause renal apoptosis and inflammation, and eventually lead to renal failure.

Transient receptor potential ankyrin 1 (TRPA1) is a non-selective cation ligand-gated channel belonging to the family of transient receptor potential (TRP) ion channels (24). Beside the major function of thermosensation and nociception $(25,26)$, the role of inflammation that TRPA1 plays has also attracted extensive research (25). The upregulation of TRPA1 function can maintain or even aggravate the inflammatory response (27). A previous study has also suggested that TRPA1 can contribute to the inflammation of the carrageenaninduced paw edema in mice via the pharmacological method (28). Meanwhile, the genetic deletion of TRPA1 reduced nociception and inflammation in monosodium urate crystal-induced gouty arthritis (29) and monosodium iodoacetate-induced arthritis (30). Recently, our lab has suggested that TRPA1 is expressed in human renal tubular epithelial cells and the hypoxia and reoxygenation that can imitate AKI significantly increases the expression of TRPA1 (unpublished data), but its function in renal tubular epithelial cells is still unclear. Thus, in this study, we explored the role of TRPA1 in DDP-induced nephrotoxicity. We hope our study can lay a foundation of the molecular regulation mechanism of TRPA1 in DDPinduced nephrotoxicity. We present the following article in accordance with the MDAR reporting checklist (available at https://dx.doi.org/10.21037/atm-21-5125).

\section{Methods}

\section{Reagents}

Capsaicin, HC-030031, BAY 11-7082, and U0126 were all purchased from Sigma-Aldrich (Merck KGaA, Darmstadt, Germany). The concentrations of the BAY11-7082, HC030031, and U0126 used in the present study were 25, 10 , and $10 \mu \mathrm{M}$, respectively. The remaining reagents utilized in the present study were of analytical purity and 
Table 1 The primary antibody used in the present study

\begin{tabular}{lccc}
\hline Reagent or resource & Source & Identifier & $\begin{array}{c}\text { Dilution } \\
\text { concentration }\end{array}$ \\
\hline Rabbit anti-caspase-3 & Abcam & ab4051 & $1: 1,000$ \\
Rabbit anti-cleaved-cas3 & Abcam & ab2302 & $1: 1,000$ \\
Rabbit anti-TRPA1 & Sigma & SAB1411593 & $1: 1,000$ \\
Rabbit anti-PARP & Abcam & ab74290 & $1: 1,000$ \\
Rabbit anti-cleaved- & Abcam & ab4830 & $1: 1,000$ \\
PARP & & & \\
Rabbit anti-iNOS & Abcam & ab178945 & $1: 1,000$ \\
Rabbit anti-IKB $\alpha$ & Abcam & ab 7217 & $1: 1,000$ \\
Rabbit anti-p-IKB $\alpha$ & Abcam & ab 24783 & $1: 1,000$ \\
Rabbit anti-IKK $\beta$ & Abcam & ab 124957 & $1: 1,000$ \\
Rabbit anti-p-IKK $\beta$ & Abcam & ab 38515 & $1: 1,000$ \\
Rabbit anti-JNK & Abcam & ab 112501 & $1: 1,000$ \\
Rabbit anti-p-JNK & Abcam & ab4821 & $1: 1,000$ \\
Rabbit anti-ERK & Abcam & ab17942 & $1: 1,000$ \\
Rabbit anti-p-ERK & Abcam & ab201015 & $1: 1,000$ \\
Rabbit anti-P38 & Abcam & ab170099 & $1: 1,000$ \\
Rabbit anti-p-P38 & Abcam & ab4822 & $1: 1,000$ \\
Rabbit anti- $\beta-a c t i n$ & Abcam & ab8227 & $1: 2,000$ \\
Goat anti-rabbit IgG H\&L & Abcam & ab6721 & $1: 5,000$ \\
\hline
\end{tabular}

commercially available.

\section{Cell culture}

The HEK293 cells (obtained from Punosai Life Technology Co., Ltd., Wuhan, China) were cultured in Dulbecco's modified Eagle medium (DMEM; Sigma, Germany) supplemented with $0.1 \%$ fetal bovine serum (FBS), $100 \mathrm{U} / \mathrm{mL}$ penicillin (Sigma, Germany), and $100 \mathrm{~g} / \mathrm{mL}$ streptomycin (Sigma, Germany). Cultures were incubated at $37^{\circ} \mathrm{C}$ with $5 \%$ carbon dioxide $\left(\mathrm{CO}_{2}\right)(31)$.

\section{Cell viability assay}

The HEK293 cells were inoculated in 96-well plates at a density of $1 \times 10^{5} /$ well and maintained for $24 \mathrm{~h}$. Then, cells were incubated with different concentrations of DDP $(0,5$, $10,20,40$, and $80 \mu \mathrm{M}$ ) for an accessional 24, 36, and $48 \mathrm{~h}$ respectively. Next, $10 \mu \mathrm{L}$ of Cell Counting Kit-8 (CCK-8;
Dojindo, Kumamoto, Japan) was appended for an incubation of $2 \mathrm{~h}$. The results were analyzed by a microplate reader (Thermo Fisher Scientific, Waltham, MA, USA) at $450 \mathrm{~nm}$.

\section{Detection of apoptosis}

After treatment with the given drugs for 48 h, the HEK293 cells were stained with $5 \mu \mathrm{L}$ allophycocyanin (APC; Sigma, Germany) and $5 \mu \mathrm{L}$ Annexin V-PE (Sigma) for $25 \mathrm{~min}$. The flow cytometry (Becton, Dickinson, and Co., Franklin Lakes, NJ, USA; FACSVerse) was used to detect the cellular apoptotic rate.

\section{Western blot analysis}

Total protein from the cell samples was extracted, and the concentration of protein was determined by the bicinchoninic acid (BCA) protein quantification kit. The assays were executed according to the previous report (32). In brief, the protein samples were separated and electrically transferred to a polyvinylidene fluoride (PVDF) membrane. The membrane was maintained with the primary antibody (Table 1) overnight at $4{ }^{\circ} \mathrm{C}$ after pre-blocking with tris-buffered saline with Tween 20 [TBST; containing 3\% bovine serum albumin (BSA)] at room temperature for $2 \mathrm{~h}$. After 3 washes with TBST, the membrane was hatched with goat-anti-mouse IgG (H\&L)-HRP or goat-anti-rabbit IgG (H\&L)-HRP (1: 5,000; Abcam, Cambridge, UK) for $2 \mathrm{~h}$ at $37^{\circ} \mathrm{C}$. An enhanced chemiluminescence kit (ECL; Affinity, San Francisco, CA, USA, KF001) was used to visualize the reaction for $1 \mathrm{~min}$.

\section{Reverse transcriptase-polymerase chain reaction (RT-PCR)}

Cell samples were used to obtain the total RNA by Animal Total RNA Isolation Kit (Foregene, Chengdu, China; RE03014) based on the operating instruction. Complementary DNA (cDNA) was synthesized with a PrimeScript RT reagent Kit (Takara, Kusatsu, Shiga, Japan; RR047A) according to the operating instruction. Quantitative RT-PCR (qRT-PCR) was executed according to the A PIKORed 96 (Thermo Fisher, USA) with the TB Green TM Premix Ex $\mathrm{Taq}^{\mathrm{TM}}$ II (Tli RNaseH Plus) (Takara, RR820A) using primers listed in Table 2 based on the previous study (33).

\section{Statistical analysis}

The one-way analysis of variance (ANOVA) and Duncan's test were utilized to analyze all the data in the present study 
Table 2 Primers used in this study

\begin{tabular}{lrr}
\hline Primer name & Forward primer $\left(5^{\prime}-3^{\prime}\right)$ & Reverse primer $\left(5^{\prime}-3^{\prime}\right)$ \\
\hline$\beta$-actin & GAAGATCAAGATCATTGCTCC & TACTCCTGCTTGCTTGCGATCCA \\
$I L-1 \beta$ & ATCCTCTCCAGTCAGGCTTCCTTGTG & AGCTCTTGTCGAGATGCTGCTGTGA \\
$I L-6$ & ACAGAGGATACCACCCACAACAGACC & CGGAACTCCAGAAGACCAGAGCAGAT \\
$T N F-\alpha$ & TGCCTGATATCGACCGAACAGCCAAC & ACAGATAGGGTCACAGCCAGTCCTCT \\
$I N F-\gamma$ & CAACCCACAGATCCAGCACAAAGC & CCCAGAATCAGCACCGACTCCTT \\
\hline
\end{tabular}

$I L-1 \beta$, interleukin-1 $\beta$; IL-6, interleukin-6; TNF- $\alpha$, tumor necrosis factor- $\alpha$; INF- $\gamma$, interferon- $\gamma$.
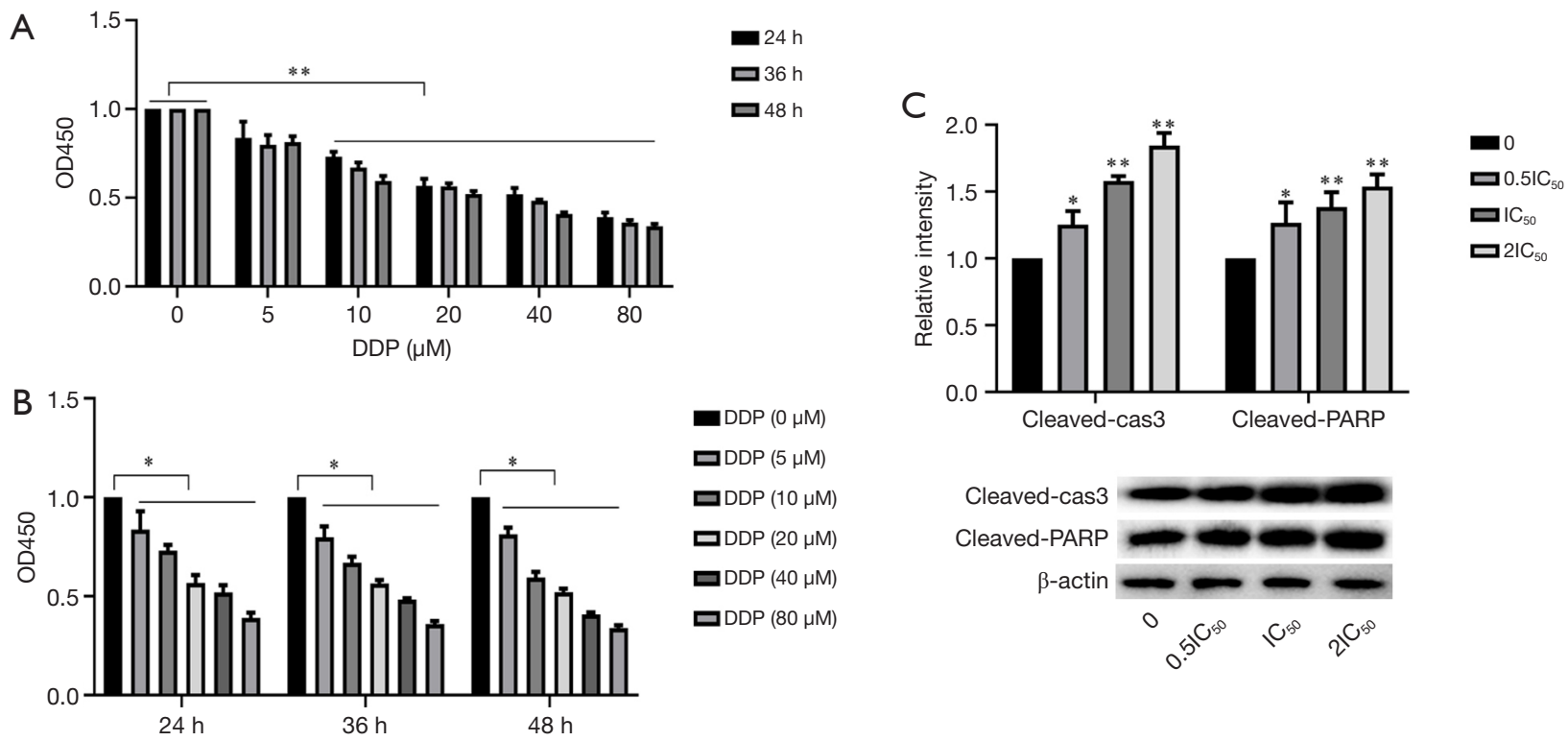

Figure 1 DDP inhibits the HEK293 cells viability and increases apoptosis. HEK293 cells were administrated with DDP with the concentration of $0,5,10,20,40$, and $80 \mu \mathrm{M}$ for 24, 36, and $48 \mathrm{~h}$, respectively. DDP reduced the HEK293 cells viability in a time-dependent (A) and dose-dependent way (B). The cleaved-cas3 and cleaved-PARP protein levels were measured using western blot (C). The means \pm SD of three independent samples were present. ${ }^{*} \mathrm{P}<0.05$ and ${ }^{* *} \mathrm{P}<0.01$, compared with 0 group. DDP, cisplatin; SD, standard deviation; cleavedcas3, cleaved-caspase3; cleaved-PARP, cleavage product of caspase-3 substrate poly-ADP-ribose polymerase.

using the software SPSS 20.0 package (SPSS Inc., Chicago, IL, USA). All data were exhibited as the means \pm standard error of the mean (SEM), and the differences were thought statistically significant and extremely significant when $\mathrm{P}<0.05$ and $\mathrm{P}<0.01$, respectively.

\section{Results}

DDP decreased cell viability and increased apoptosis of HEK293 cells

To detect the HEK293 cells viability caused by DDP,
HEK293 cells were treated with DDP at the concentrations of $0,5,10,20,40$, and $80 \mu \mathrm{M}$ for 24,36 , and $48 \mathrm{~h}$, respectively. Then the cell viability was evaluated using the CCK-8 kit. The results revealed that $10 \mu \mathrm{M}$ DDP is obviously cytotoxic for HEK293 cells, and DDP declined the cell viability both in a time-dependent and dosedependent manner (Figure 1A,1B). Meanwhile, the $\mathrm{IC}_{50}$ of DDP for HEK293 cells was $25.03 \mu \mathrm{M}$ at $48 \mathrm{~h}$. To deeply evaluate the effect of DDP on HEK293 cells, we assessed the apoptosis of HEK293 cells treat with DDP with the concentration of $0,0.5 \mathrm{IC}_{50}, \mathrm{IC}_{50}$, and $2 \mathrm{IC}_{50}$ using the apoptosis-related protein. The results showed that 

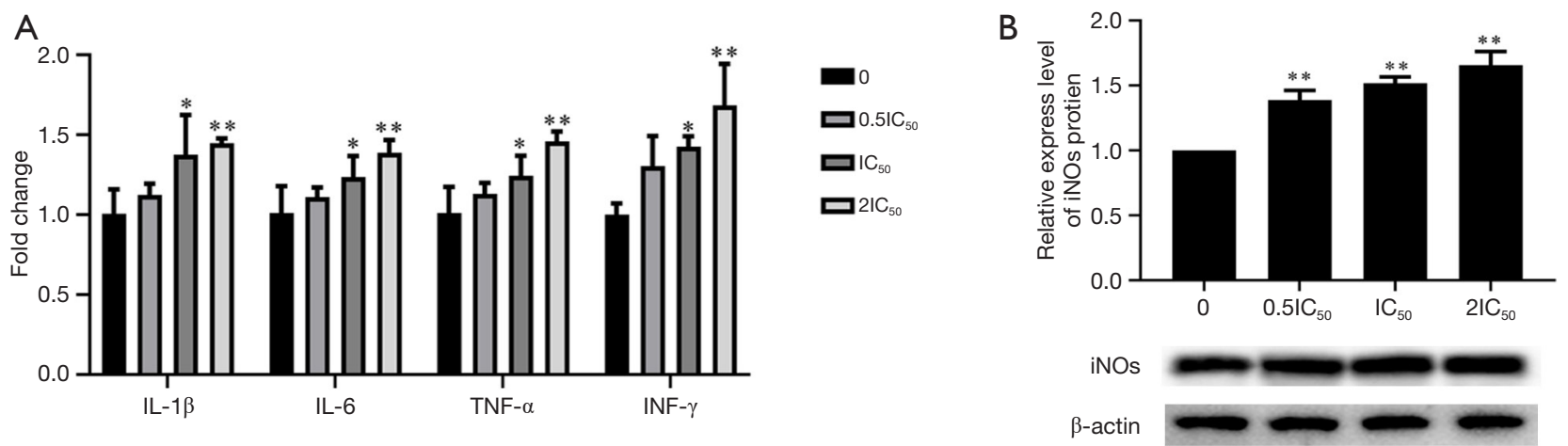

Figure 2 DDP boosted the inflammatory of HEK293 cells. HEK293 cells were administrated with DDP with the concentration of 0, $0.5 \mathrm{IC}_{50}, \mathrm{IC}_{50}$ and $2 \mathrm{IC}_{50}$ respectively. The expression level of $I L-1 \beta, I L-6, T N F-\alpha$, and $I N F-\gamma$ was detected by qRT-PCR (A). Also, the level of iNOS (B) was examined using western blot analysis respectively. The means \pm SD of three independent samples were shown. The results were exhibited after being normalized to $\beta$-actin. ${ }^{*} \mathrm{P}<0.05$ and ${ }^{* *} \mathrm{P}<0.01$, compared with 0 group. DDP, cisplatin; $I L-1 \beta$, interleukin-1 $\beta$; $I L-6$, interleukin-6; $T N F-\alpha$, tumor necrosis factor- $\alpha$; INF- $\gamma$, interferon- $\gamma$; qRT-PCR, quantitative reverse transcription-polymerase chain reaction; iNOS, inducible nitric oxide synthase; SD, standard deviation.

the expression of cleaved-caspase 3 (cleaved-cas3) and the cleavage product of caspase- 3 substrate poly-ADP-ribose polymerase (cleaved-PARP) were elevated after HEK293 cells were treated with DDP in a dose-dependent way (Figure 1C).

\section{DDP promoted HEK293 cells inflammation}

Beside the renal apoptosis (13), renal inflammation (14) has also been noted as one of major factors of DDPinduced AKI. Thus, we explored the effect of DDP on the inflammation of HEK293 cells. Firstly, the expression of some typical pro-inflammatory factors such as $I L-1 \beta$, $I L-6, T N F-\alpha$, and $I N F-\gamma$ was detected in DDP-treated HEK293 cells using qRT-PCR. The results revealed that DDP treatment enhanced the $I L-1 \beta, I L-6, T N F-\alpha$, and $I N F-\gamma$ expression in a dose-dependent manner (Figure $2 A$ ). Subsequently, as one of most important inflammatory mediators, iNOS level also was determined using western blot analysis. Consistently, the expression of iNOS was improved after HEK293 cells were treated with DDP in a dose-dependent fashion (Figure 2B).

\section{DDP acted on the MAPK/NF- $\mathrm{KB}$ signaling patbway}

Due to its significance in the apoptosis- and inflammationrelated signaling pathway, the expression of IKK $\beta$ involved in NF- $\kappa$ B signaling pathway was evaluated after HEK293 cells were treated with DDP using western blot analysis.
As shown in Figure 3A, the phosphorylation expression of IKK $\beta$ as well as the ratio of phosphorylation expression of IKK $\beta$ and total expression of IKK $\beta$ (p-IKK $\beta /$ IKK $\beta$ ) were increased in a dose-dependent manner. As one of most vital transducers of upstream signaling of NF- $\mathrm{kB}$, the expression of proteins involved in the MAPK signaling pathway was determined after HEK293 cells were induced with DDP using western blot analysis. Equally, the phosphorylation level of JNK, ERK and p38, and p-JNK/JNK, p-ERK/ERK and $\mathrm{p}-\mathrm{p} 38 / \mathrm{p} 38$ were enhanced in a dose-dependent manner. These results indicated that DDP treatment activated the NF- $\kappa B$ and MAPK signaling pathways in HEK293 cells, respectively.

To further confirm the inhibitory effect of DDP on the NF- $\mathrm{KB}$ signaling pathway, we detected the expression of $I L-1 \beta, I L-6, T N F-\alpha$, and $I N F-\gamma$ by qRT-PCR, and the level of iNOS by western blot analysis after HEK293 cells had been incubated with the specific inhibitor of NF- $\mathrm{kB}$, BAY 11-7082. As shown in Figure 3B,3C, for both the expression level of $I L-1 \beta, I L-6, T N F-\alpha$, and $I N F-\gamma$ and the expression of iNOS protein, BAY 11-7082 alone could obviously inhibit the expression, and BAY 11-7082 combined with DDP further diminished the expression compared with DDP alone. To verify that MAPK signaling occurred upstream of the NF- $\kappa B$ signaling pathway, the expression of IKK $\beta$ was detected after HEK293 cells had been incubated with the pan-MAPK inhibitor, U0126. As shown in Figure 3D,3E, for both the expression level of $I L-1 \beta, I L-6, T N F-\alpha$, and $I N F-\gamma$ and the expression 
of iNOS protein, U0126 alone could obviously inhibit the expression, and U0126 combined with DDP further diminished the expression compared with DDP alone. In addition, the results revealed that U0126 treatment inhibited the activity of MAPKs and decreased the phosphorylation expression of IKK $\beta$, while increased the phosphorylation level of IкB $\alpha$ (Figure $3 F$ ). These results showed that DDP activated the MAPK/NF- $\mathrm{KB}$ signaling pathway in HEK293 cells.

\section{DDP enhanced the level of TRPA1}

Since our previous study exhibited that the hypoxia and reoxygenation notably enhances the level of TRPA1, we detected the TRPA1 expression using western blot. Consistently, the messenger RNA (mRNA) and protein level of TRPA1 were elevated in a dose-dependent way after HEK293 cells were treated with DDP (Figure 4A). Moreover, BAY 11-7082 combined with DDP reduced

A
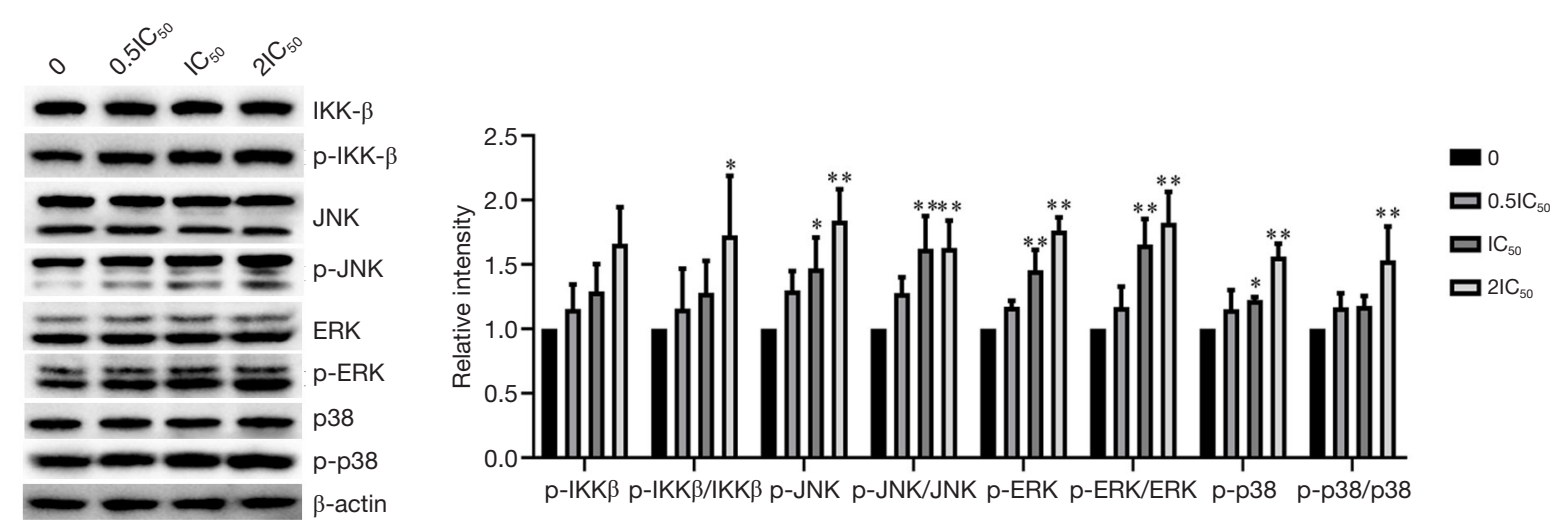

B
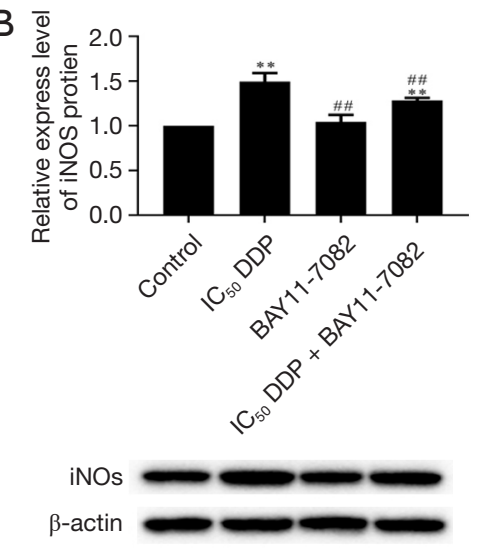

C
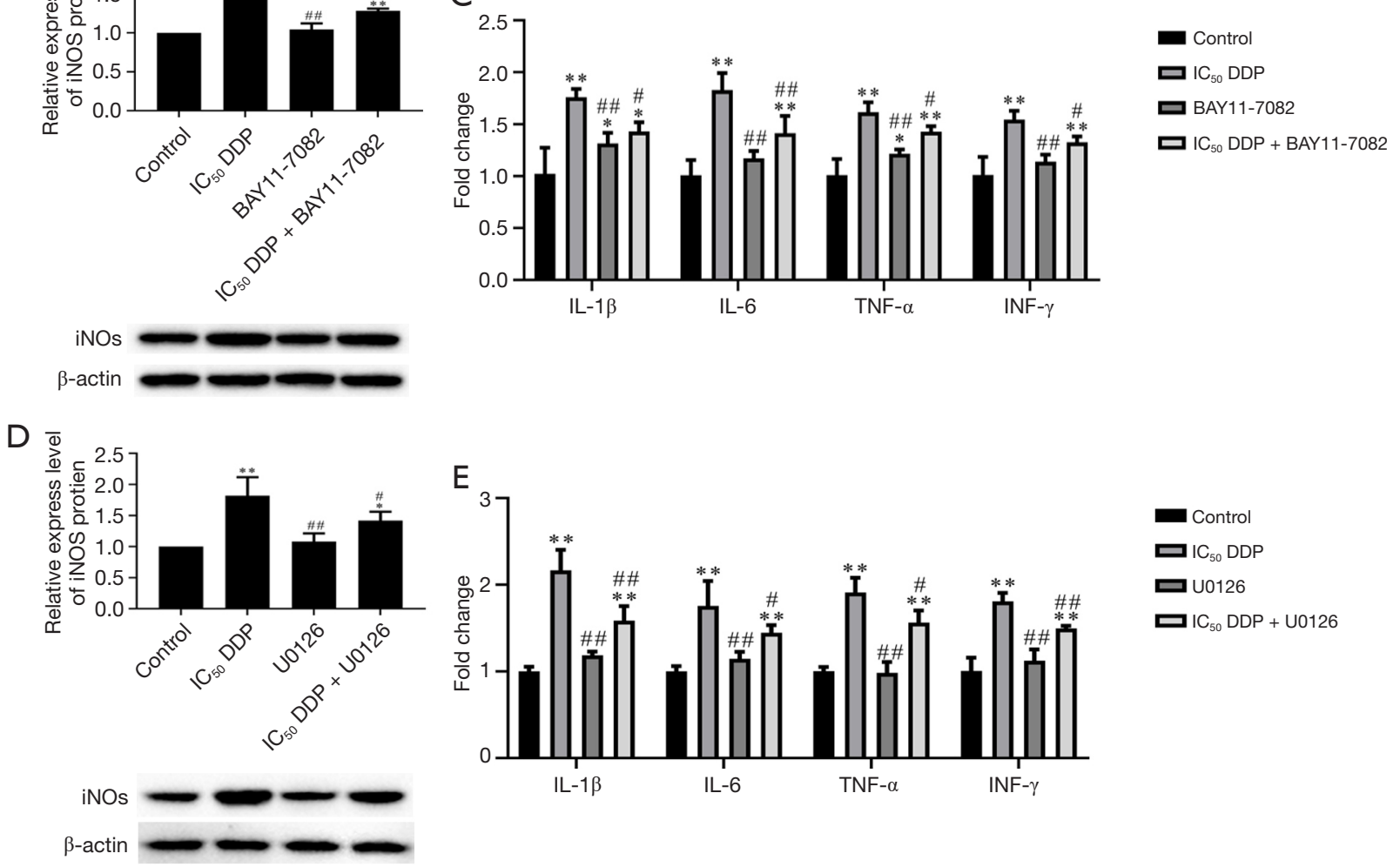

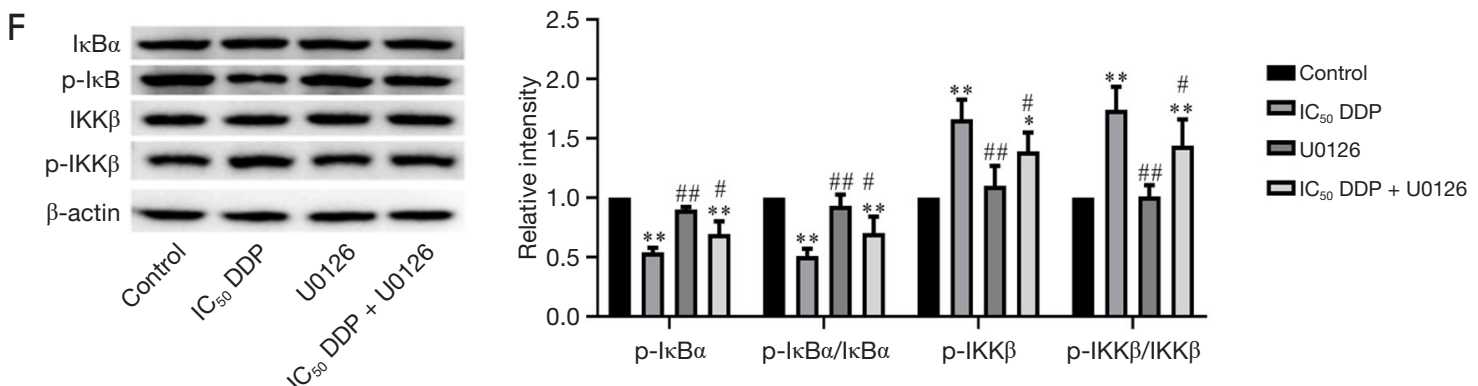

Figure 3 DDP influenced the MAPK/NF- $\mathrm{BB}$ signaling pathway. HEK293 cells were treated with DDP at the concentrations of 0, $0.5 \mathrm{IC}_{50}$, $\mathrm{IC}_{50}$, and $2 \mathrm{IC}_{50}$, respectively. The expression level of IKK $\beta$, p-IKK $\beta$, JNK, p- JNK, ERK, p-ERK, p38, and p-p38 (A) were examined by western blot assay. Then, HEK293 cells were treated with $\mathrm{IC}_{50}$ DDP, BAY 11-7082, IC 50 DDP + BAY 11-7082 or PBS (control) respectively. The expression of iNOS protein (B) and the expression of $I L-1 \beta, I L-6, T N F-\alpha$, and $I N F-\gamma(C)$ was examined by western blot and qRT-PCR analysis. After HEK293 cells were treated with $\mathrm{IC}_{50}$ DDP, U0126, IC ${ }_{50}$ DDP + U0126 or PBS (control) respectively, the expression of iNOS protein (D), the expression level of $I L-1 \beta, I L-6, T N F-\alpha$, and $I N F-\gamma$ mRNA (E), and (F) the expression of I $\mathrm{BB} \alpha, \mathrm{p}-\mathrm{I} \kappa \mathrm{B} \alpha, \mathrm{IKK} \beta$, and $\mathrm{p}-\mathrm{IKK} \beta$ protein was determined using western blot analysis and qRT-PCR analysis. The means \pm SD of three independent samples were exhibited. The data were analyzed after being normalized to $\beta$-actin. ${ }^{*} \mathrm{P}<0.05$ and ${ }^{* *} \mathrm{P}<0.01$, compared with $0 /$ control group; ${ }^{\#} \mathrm{P}<0.05$ and ${ }^{\# \#} \mathrm{P}<0.01$, compared with $\mathrm{IC}_{50}$ DDP group. DDP, cisplatin; PBS, phosphate-buffered saline; iNOS, inducible nitric oxide synthase; $I L-1 \beta$, interleukin$1 \beta$; IL-6, interleukin-6; TNF- $\alpha$, tumor necrosis factor- $\alpha$; INF- $\gamma$, interferon- $\gamma$; qRT-PCR, quantitative reverse transcription-polymerase chain reaction; mRNA, messenger RNA; $\mathrm{SD}$, standard deviation.
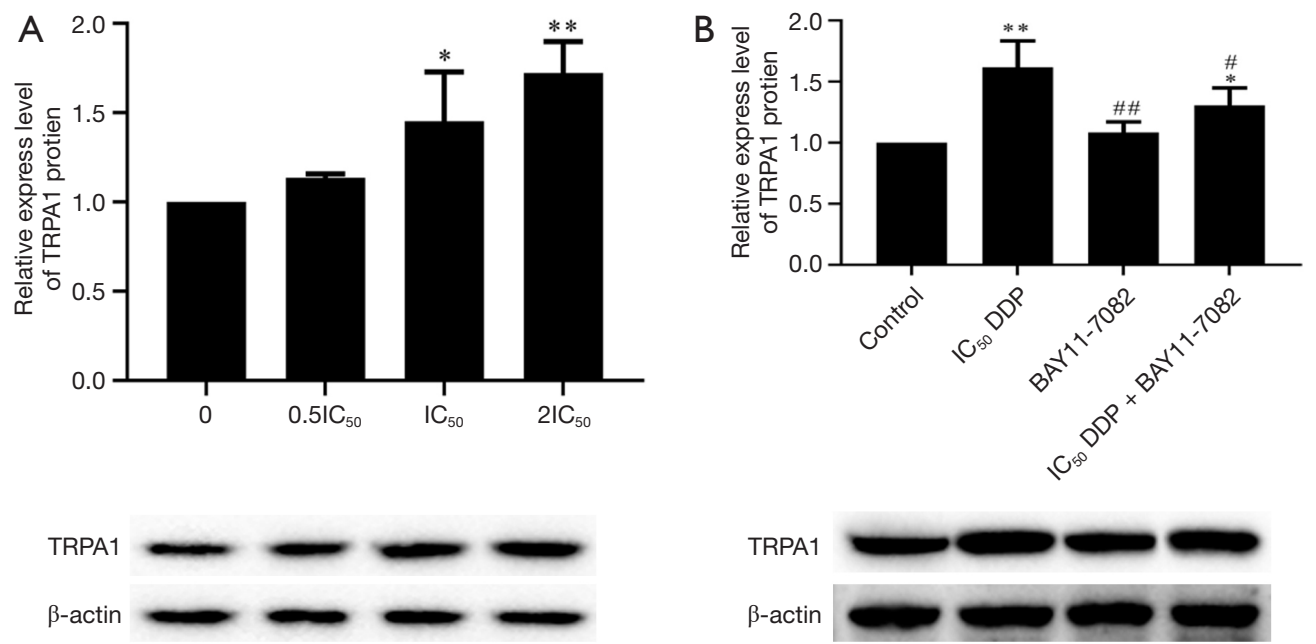

Figure 4 The TRPA1 expression was increased both at mRNA and protein levels in a dose-dependent manner. HEK293 cells were administrated with DDP with the concentration of $0,0.5 \mathrm{IC}_{50}, \mathrm{IC}_{50}$, and $2 \mathrm{IC}_{50}(\mathrm{~A})$, or $\mathrm{IC}_{50} \mathrm{DDP}, \mathrm{BAY} 11-7082, \mathrm{IC}_{50} \mathrm{DDP}+\mathrm{BAY}_{11-7082}$ or PBS (control) (B) respectively. The TRPA1 expression was examined using western blot analysis. The means \pm SD of three independent samples were exhibited. The results were analyzed after being normalized to $\beta$-actin. ${ }^{*} \mathrm{P}<0.05$ and ${ }^{* *} \mathrm{P}<0.01$, compared with $0 /$ control group; ${ }^{\#} \mathrm{P}<0.05$ and ${ }^{\# \#} \mathrm{P}<0.01$, compared with $\mathrm{IC}_{50}$ DDP group. DDP, cisplatin; PBS, phosphate-buffered saline; SD, standard deviation. 

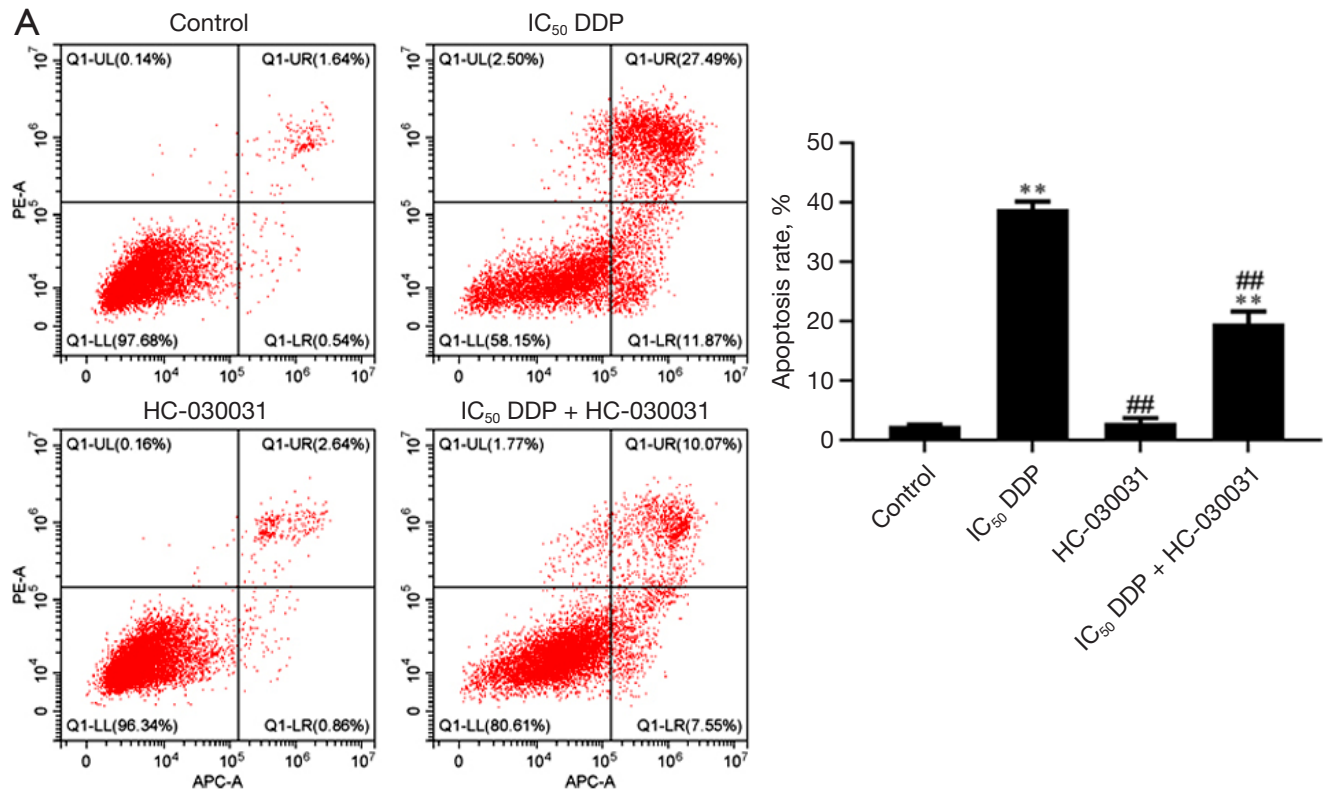

B
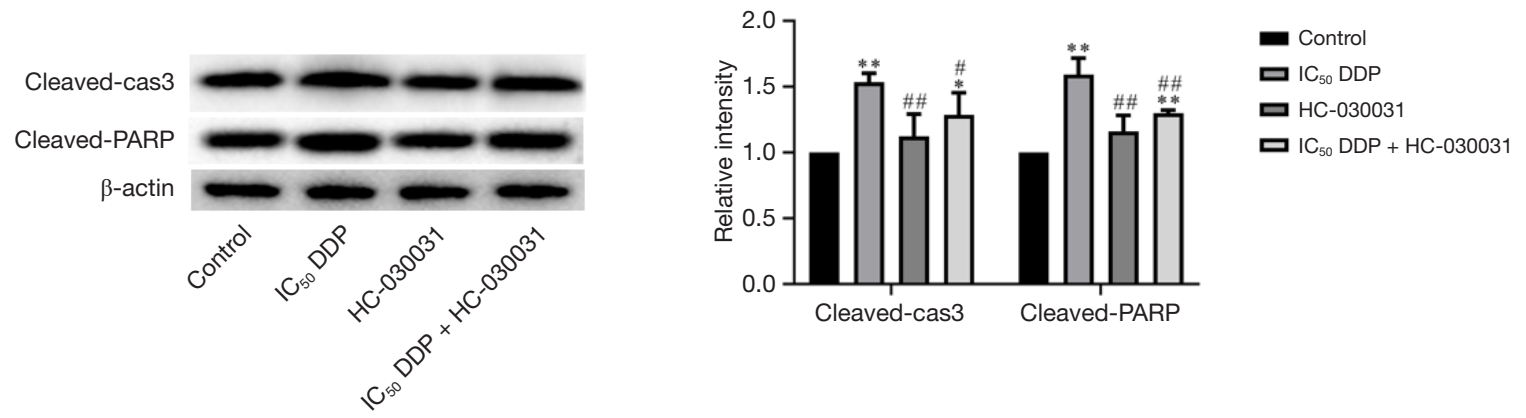

Figure 5 HC-030031 relieved the apoptosis and the expression level of apoptosis-related proteins. HEK293 cells were treated with $\mathrm{IC}_{50}$ DDP, HC-030031, IC 50 DDP + HC-030031, or PBS (control), respectively. The apoptotic of the HEK293 cells was determined via flow cytometry after PE and APC co-staining (A), and the expression level of cleaved-cas3 and cleaved-PARP was examined by western blot (B). The means $\pm \mathrm{SD}$ of three independent samples were shown. The results were shown after being normalized to $\beta$-actin. $\beta$-actin. ${ }^{*} \mathrm{P}<0.05$ and ${ }^{* *} \mathrm{P}<0.01$, compared with control group; ${ }^{\#} \mathrm{P}<0.05$ and ${ }^{\# \#} \mathrm{P}<0.01$, compared with $\mathrm{IC}_{50}$ DDP group. DDP, cisplatin; PBS, phosphate-buffered saline; PE, phycoerythrin; APC, allophycocyanin; cleaved-cas3, cleaved-caspase3; cleaved-PARP, cleavage product of caspase-3 substrate poly-ADP-ribose polymerase; SD, standard deviation.

TRPA1 expression compared with DDP alone (Figure 4B).

\section{TRPA1 antagonist HC-030031 alleviated DDP-induced apoptosis}

To elucidate the effects of TRPA1 on DDP-induced apoptosis, the pharmacological blocker was incubated with the HEK293 cells that had been treated with DDP. The TRPA1 antagonist, HC-030031, could distinctly alleviate the HEK293 cells apoptosis caused by DDP (Figure 5A). Additionally, HC-030031 also reduced the up-regulation of caspase3, cleaved-cas3, PARP, and cleaved-PARP induced by DDP (Figure 5B). Certainly, the HC-030031 alone had no effect on both the HEK293 cells apoptosis and the protein expression compared with control.

\section{TRPA1 antagonist HC-030031 relieved DDP-induced inflammation}

The effect of HC-030031 on DDP-induced inflammation also was assessed with the HEK293 cells induced with DDP. It was revealed that HC-030031 reduced the upregulation of 

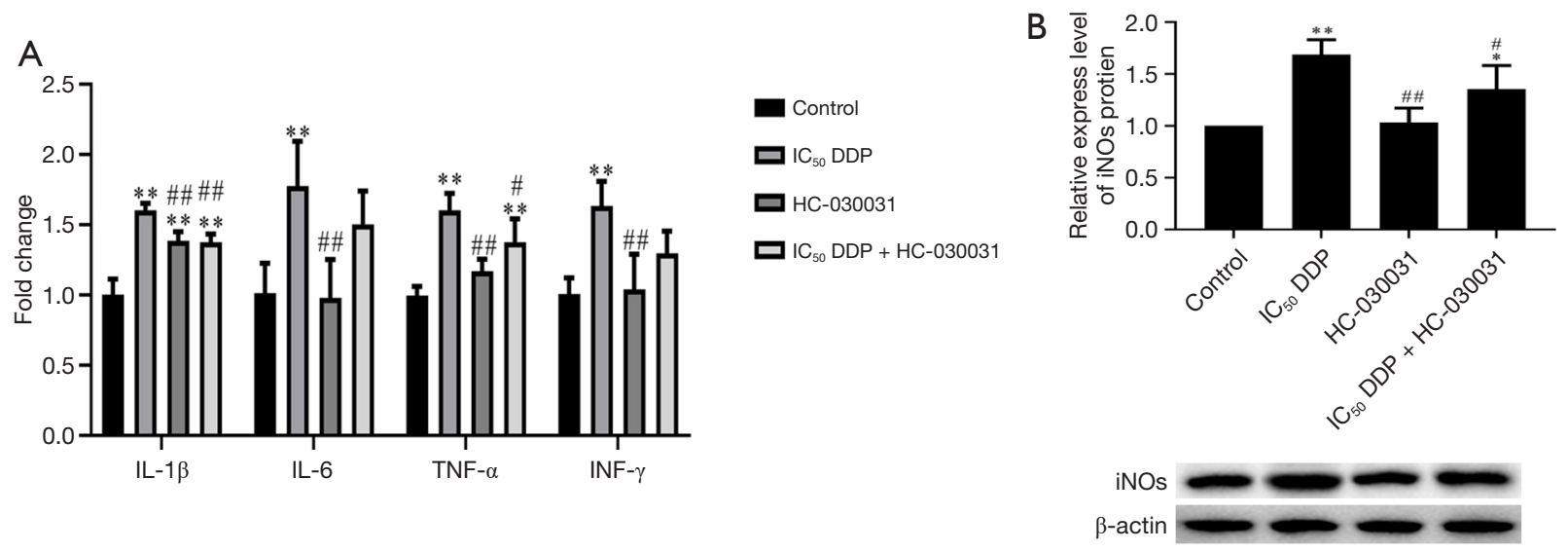

Figure 6 HC-030031 alleviated the inflammation. HEK293 cells were treated with $\mathrm{IC}_{50}$ DDP, HC-030031, IC 50 DDP + HC-03003, or PBS (control), respectively. The expression level of $I L-1 \beta, I L-6, T N F-\alpha$, and $I N F-\gamma$ of the HEK293 cells was determined by qRT-PCR (A), and the expression of iNOS was determined via western blot (B). The means \pm SD of three independent samples were present. The results were shown after being normalized to $\beta$-actin. ${ }^{*} \mathrm{P}<0.05$ and ${ }^{* *} \mathrm{P}<0.01$, compared with control group; ${ }^{\#} \mathrm{P}<0.05$ and ${ }^{\# \#} \mathrm{P}<0.01$, compared with $\mathrm{IC} \mathrm{C}_{50}$ DDP group. DDP, cisplatin; PBS, phosphate-buffered saline; $I L-1 \beta$, interleukin-1 $\beta$; $I L-6$, interleukin- 6 ; $T N F-\alpha$, tumor necrosis factor- $\alpha$; $I N F-\gamma$, interferon- $\gamma$; qRT-PCR, quantitative reverse transcription-polymerase chain reaction; iNOS, inducible nitric oxide synthase; SD, standard deviation.

$I L-1 \beta, I L-6, T N F-\alpha$, and $I N F-\gamma$ induced by DDP (Figure $6 A$ ), and also reduced the up-regulation of iNOS induced by DDP (Figure 6B).

\section{TRPA1 antagonist HC-030031 inbibited the MAPK/NF- $\mathrm{B}$ signaling pathway}

As shown in Figure 7, the expression of $\operatorname{I\kappa B} \alpha$, IKK $\beta$, JNK, ERK, and p38 that are involved in the MAPK/ NF- $\kappa \mathrm{B}$ signaling pathway did not reduce with HC030031 treatment compared with those treated with DDP. However, the phosphorylation expression of IKK $\beta$, JNK, ERK, and p38 decreased, while that of I $\mathrm{KB} \alpha$ increased compared with DPP treatment.

\section{Discussion}

Due to its remarkable effect on a series of malignant solid tumors, DDP has been one of most commonly drugs used in cancer therapy. Nevertheless, adverse effects including nephrotoxicity have become the main issue restricting its use and efficacy in cancer chemotherapy. Our previous study exhibited that the hypoxia and reoxygenation which can stimulate AKI prominently enhanced the expression of TRPA1, which indicated that TRPA1 might play an important role in DDP-associated nephrotoxicity. In this study, we first reported that TRPA1 mediated DDP-induced cellular inflammation and apoptosis via the MAPK/NF- $\mathrm{KB}$ signal pathway in HEK293 cells in vitro.

TRPV1 is a powerful non-selective $\mathrm{Ca}^{2+}$ channel, thus our recent study has showed that TRPV1 mediates DDPinduced apoptosis in renal tubular cells via calciumdependent signaling pathway (34). Besides, Ta et al. (35) has shown that DDP induced up-regulation of TRPA1 mRNA both in vitro and in vivo. However, more molecular mechanism related in the role of TRPV1 in DDP-induced apoptosis also need further researches. Prominently, oxidative stress is closely related in the pathogenesis of DDP-induced nephrotoxicity and extremely drives to apoptotic cell death both in vivo $(36,37)$ and in vitro (38). Furthermore, a large numbers of studies have showed that inflammation response is also involved in the pathogenesis of DDP-induced nephrotoxicity (39-41).

In our study, we found that DDP could induce HEK293 cell apoptosis while decreasing the cell viability and increasing the nuclear degradation in a dose-dependent manner. Activation of caspase 3 can cleave its substrate protein PARP to lead to protein disintegration and apoptosis (42). Thus, caspase 3 and PARP play an important role in apoptosis (43). Consequently, the expression of cleaved-cas 3 and cleaved PARP also increased after HEK293 cells were treated with DDP in a dose-dependent way. Therefore, DDP induced 


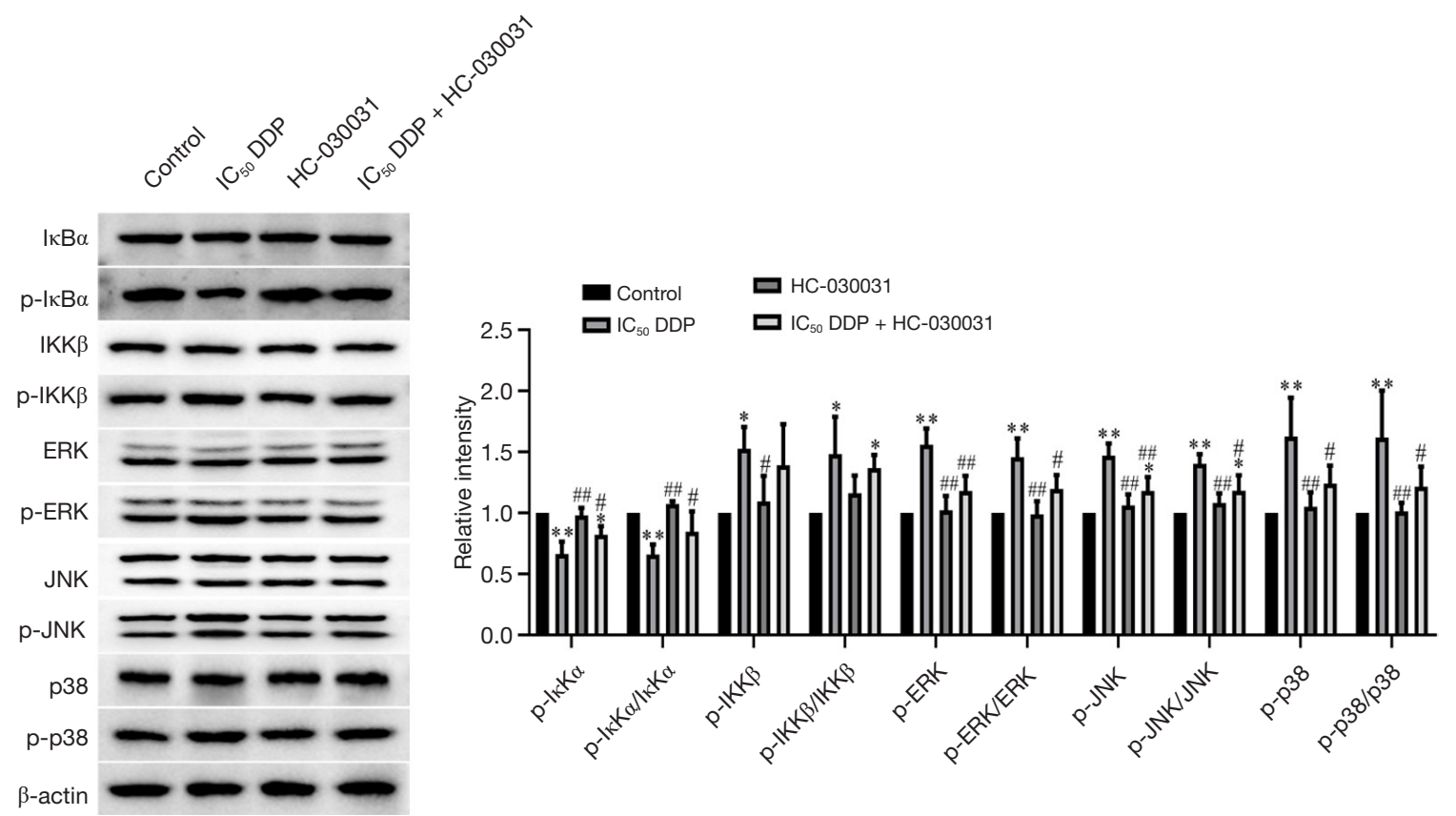

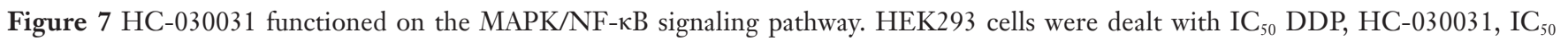

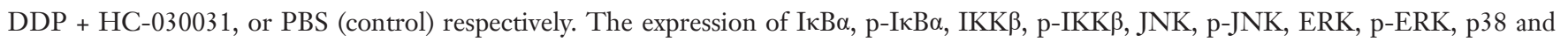
p-p38 was examined using western blot assay. The means \pm SD of three independent samples were shown. The data were exhibited after being normalized to $\beta$-actin. ${ }^{*} \mathrm{P}<0.05$ and ${ }^{*} \mathrm{P}<0.01$, compared with control group; ${ }^{*} \mathrm{P}<0.05$ and ${ }^{\# \#} \mathrm{P}<0.01$, compared with $\mathrm{IC} \mathrm{C}_{50} \mathrm{DDP}$ group. DDP, cisplatin; PBS, phosphate-buffered saline; mRNA, messenger RNA; SD, standard deviation.

apoptosis of HEK293 cells, which is in line with earlier reports $(44,45)$. Additionally, treatment with the TRPA1 antagonist HC-030031 also decreased the apoptosis and expression of cleaved-cas3 and cleaved PARP, which indicated that TRPA1 mediates the apoptosis induced by DDP.

Earlier research has suggested that apoptosis is closely connected with the production and release of a series of inflammatory cytokines and mediators, including IL-1 $\beta$, IL-6, TNF- $\alpha$, INF- $\gamma$, and iNOS $(46,47)$. Our results verified the DDP-induced inflammatory response through the rise of expression level of IL-1 $\beta$, IL- 6 , TNF- $\alpha$, and INF- $\gamma$, and iNOS protein. More importantly, the previous research indicated that the NF- $\mathrm{NB}$ signaling pathway is involved in inflammation induced by DDP (48). Upon the specific inhibitor I $\mathrm{B}$ activation, NF- $\kappa \mathrm{B}$ is activated with the removal of IкB by IKK $\alpha / \beta(49,50)$. The results revealed that the phosphorylation of IKK $\beta$ was activated with DDP treatment. The use of BAY371 11-7082 further supported that the release of IL- $1 \beta$, IL- 6 , TNF- $\alpha$, and INF- $\gamma$, and iNOS is NF- $\mathrm{BB}$ signaling pathway-dependent. More importantly, the TRPA1 antagonist HC-030031 treatment also decreased the expression level of IL-1 $\beta$, IL- 6 , TNF- $\alpha$, and INF- $\gamma$, and iNOS protein, which suggested that TRPA1 is associated with the NF- $\kappa \mathrm{B}$ signaling pathway. As one of the most important signaling pathways in upstream signaling of NF- $\kappa \mathrm{B}$, the MAPK signaling pathway has been reported as associated with DDP-induced renal cell death (6). Among the MAPK signaling pathway, JNK leads to inflammation, apoptosis, and even kidney dysfunction upon activation by DDP (51), and ERK declines the level of apoptosis-related protein during DDP-induced renal cell death (52), additionally p38 mediates inflammation, oxidative stress, and apoptosis after the initiation of DDPinduced renal damage (53). Similarly, the phosphorylation JNK, ERK, and p38 were activated with DDP treatment. Treatment with U0126 inhibits the phosphorylation activity of p65 and IKK $\beta$, suggesting that the MAPK signaling pathway is associated with the NF- $\mathrm{KB}$ signaling pathwaydependent inflammatory progress. Moreover, the TRPA1 antagonist HC-030031 treatment also decreased the expression of phosphorylation I $\mathrm{BB} \alpha$, IKK $\beta$, JNK, ERK, and p38 compared with DPP treatment, which indicated that TRPA1 is associated with DDP-induced nephrotoxicity via the MAPK/NF- $\kappa B$ signaling pathway. 
In summary, this study demonstrated that TRPA1 regulates phosphorylation of the MAPK/NF- $\mathrm{KB}$ signaling pathway to promote the production and release of inflammatory cytokines and mediators, which causes apoptosis and eventually nephrotoxicity. However, there are also some limitations of this article, for example, the role of TRPA1 in DDP-induced nephrotoxicity in the animal models will consider in future research. I n brief, our study may provide a novel insight into the molecular mechanism of TRPA1 in DDP-induced nephrotoxicity.

\section{Acknowledgments}

Funding: This work was supported by the Sichuan Science and Technology Program (2019YFH0069), Sichuan Medical Research Project (S20014), Chengdu Medical Research Project (2020208), and the Scientific Research Project of Sichuan Provincial People's Hospital (2018LY12\&2014006).

\section{Footnote}

Reporting Checklist: The authors have completed the MDAR reporting checklist. Available at https://dx.doi. org/10.21037/atm-21-5125

Data Sharing Statement: Available at https://dx.doi. org/10.21037/atm-21-5125

Conflicts of Interest: All authors have completed the ICMJE uniform disclosure form (available at https://dx.doi. org/10.21037/atm-21-5125). The authors have no conflicts of interest to declare.

Ethical Statement: The authors are accountable for all aspects of the work in ensuring that questions related to the accuracy or integrity of any part of the work are appropriately investigated and resolved.

Open Access Statement: This is an Open Access article distributed in accordance with the Creative Commons Attribution-NonCommercial-NoDerivs 4.0 International License (CC BY-NC-ND 4.0), which permits the noncommercial replication and distribution of the article with the strict proviso that no changes or edits are made and the original work is properly cited (including links to both the formal publication through the relevant DOI and the license). See: https://creativecommons.org/licenses/by-ncnd/4.0/.

\section{References}

1. Rosenberg B, Vancamp L, Krigas T. Inhibition of cell division in Escherichia coli by electrolysis products from a platinum electrode. Nature 1965;205:698-9.

2. Wang D, Lippard SJ. Cellular processing of platinum anticancer drugs. Nat Rev Drug Discov 2005;4:307-20.

3. Cohen SM, Lippard SJ. Cisplatin: from DNA damage to cancer chemotherapy. Prog Nucleic Acid Res Mol Biol 2001;67:93-130.

4. Arany I, Safirstein RL. Cisplatin nephrotoxicity. Semin Nephrol 2003;23:460-4.

5. Siddik ZH. Cisplatin: mode of cytotoxic action and molecular basis of resistance. Oncogene 2003;22:7265-79.

6. Pabla N, Dong Z. Cisplatin nephrotoxicity: mechanisms and renoprotective strategies. Kidney Int 2008;73:994-1007.

7. Hartmann JT, Fels LM, Knop S, et al. A randomized trial comparing the nephrotoxicity of cisplatin/ifosfamidebased combination chemotherapy with or without amifostine in patients with solid tumors. Invest New Drugs 2000;18:281-9.

8. Hartmann JT, Lipp HP. Toxicity of platinum compounds. Expert Opin Pharmacother 2003;4:889-901.

9. Sastry J, Kellie SJ. Severe neurotoxicity, ototoxicity and nephrotoxicity following high-dose cisplatin and amifostine. Pediatr Hematol Oncol 2005;22:441-5.

10. Abdel-Razek EA, Abo-Youssef AM, Azouz AA. Benzbromarone mitigates cisplatin nephrotoxicity involving enhanced peroxisome proliferator-activated receptor-alpha (PPAR- $\alpha$ ) expression. Life Sci 2020;243:117272.

11. Beyer J, Rick O, Weinknecht S, et al. Nephrotoxicity after high-dose carboplatin, etoposide and ifosfamide in germcell tumors: incidence and implications for hematologic recovery and clinical outcome. Bone Marrow Transplant 1997;20:813-9.

12. Miller RP, Tadagavadi RK, Ramesh G, et al. Mechanisms of Cisplatin nephrotoxicity. Toxins (Basel) 2010;2:2490-518.

13. Song KI, Park JY, Lee S, et al. Protective effect of tetrahydrocurcumin against cisplatin-induced renal damage: in vitro and in vivo studies. Planta Med 2015;81:286-91.

14. Faubel S, Lewis EC, Reznikov L, et al. Cisplatininduced acute renal failure is associated with an increase in the cytokines interleukin (IL)-1beta, IL-18, IL-6, and neutrophil infiltration in the kidney. J Pharmacol Exp Ther 2007;322:8-15.

15. Lieberthal W, Triaca V, Levine J. Mechanisms of death 
induced by cisplatin in proximal tubular epithelial cells: apoptosis vs. necrosis. Am J Physiol 1996;270:F700-8.

16. Atessahin A, Yilmaz S, Karahan I, et al. Effects of lycopene against cisplatin-induced nephrotoxicity and oxidative stress in rats. Toxicology 2005;212:116-23.

17. Chirino YI, Sánchez-González DJ, Martínez-Martínez CM, et al. Protective effects of apocynin against cisplatininduced oxidative stress and nephrotoxicity. Toxicology 2008;245:18-23.

18. Kuhad A, Tirkey N, Pilkhwal S, et al. Renoprotective effect of Spirulina fusiformis on cisplatin-induced oxidative stress and renal dysfunction in rats. Ren Fail 2006;28:247-54.

19. Kruidering M, Van de Water B, de Heer E, et al. Cisplatin-induced nephrotoxicity in porcine proximal tubular cells: mitochondrial dysfunction by inhibition of complexes I to IV of the respiratory chain. J Pharmacol Exp Ther 1997;280:638-49.

20. Malik S, Suchal K, Gamad N, et al. Telmisartan ameliorates cisplatin-induced nephrotoxicity by inhibiting MAPK mediated inflammation and apoptosis. Eur J Pharmacol 2015;748:54-60.

21. Sahu BD, Kalvala AK, Koneru M, et al. Ameliorative effect of fisetin on cisplatin-induced nephrotoxicity in rats via modulation of NF- $\kappa \mathrm{B}$ activation and antioxidant defence. PLoS One 2014;9:e105070.

22. Amirshahrokhi K, Khalili AR. Thalidomide ameliorates cisplatin-induced nephrotoxicity by inhibiting renal inflammation in an experimental model. Inflammation 2015;38:476-84.

23. El-Naga RN. Pre-treatment with cardamonin protects against cisplatin-induced nephrotoxicity in rats: impact on NOX-1, inflammation and apoptosis. Toxicol Appl Pharmacol 2014;274:87-95.

24. Nilius B, Prenen J, Owsianik G. Irritating channels: the case of TRPA1. J Physiol 2011;589:1543-9.

25. Zygmunt PM, Högestätt ED. TRPA1. Handb Exp Pharmacol 2014;222:583-630.

26. Koivisto A, Chapman H, Jalava N, et al. TRPA1: a transducer and amplifier of pain and inflammation. Basic Clin Pharmacol Toxicol 2014;114:50-5.

27. Andersson DA, Gentry C, Bevan S. TRPA1 has a key role in the somatic pro-nociceptive actions of hydrogen sulfide. PLoS One 2012;7:e46917.

28. Moilanen LJ, Laavola M, Kukkonen M, et al. TRPA1 contributes to the acute inflammatory response and mediates carrageenan-induced paw edema in the mouse. Sci Rep 2012;2:380.
29. Moilanen LJ, Hämäläinen M, Lehtimäki L, et al. Urate crystal induced inflammation and joint pain are reduced in transient receptor potential ankyrin 1 deficient mice-potential role for transient receptor potential ankyrin 1 in gout. PLoS One 2015;10:e0117770.

30. Moilanen LJ, Hämäläinen M, Nummenmaa E, et al. Monosodium iodoacetate-induced inflammation and joint pain are reduced in TRPA1 deficient mice--potential role of TRPA1 in osteoarthritis. Osteoarthritis Cartilage 2015;23:2017-26.

31. Azad MA, Roberts KD, Yu HH, et al. Significant accumulation of polymyxin in single renal tubular cells: a medicinal chemistry and triple correlative microscopy approach. Anal Chem 2015;87:1590-5.

32. Xie Y, Chen S, Yan Y, et al. Potential of recombinant inorganic pyrophosphatase antigen as a new vaccine candidate against Baylisascaris schroederi in mice. Vet Res 2013;44:90.

33. Wang T, Huang W, Costa MM, et al. Two copies of the genes encoding the subunits of putative interleukin (IL)4/IL-13 receptors, IL-4R $\alpha, \mathrm{IL}-13 \mathrm{R} \alpha 1$ and IL-13R $\alpha 2$, have been identified in rainbow trout (Oncorhynchus mykiss) and have complex patterns of expression and modulation. Immunogenetics 2011;63:235-53.

34. Meng X, Zhang Y, Ma Y, et al. Transient receptor potential ankyrin 1 mediates cisplatin-induced apoptosis in renal tubular cells via calcium-dependent signaling pathway. Ann Palliat Med 2021;10:9025-38.

35. Ta LE, Bieber AJ, Carlton SM, et al. Transient Receptor Potential Vanilloid 1 is essential for cisplatin-induced heat hyperalgesia in mice. Mol Pain 2010;6:15.

36. Badawy AM, El-Naga RN, Gad AM, et al. Wogonin pretreatment attenuates cisplatin-induced nephrotoxicity in rats: Impact on PPAR- $\gamma$, inflammation, apoptosis and Wnt/ $\beta$-catenin pathway. Chem Biol Interact 2019;308:137-46.

37. Soetikno V, Sari SDP, Ul Maknun L, et al. Pre-Treatment with Curcumin Ameliorates Cisplatin-Induced Kidney Damage by Suppressing Kidney Inflammation and Apoptosis in Rats. Drug Res (Stuttg) 2019;69:75-82.

38. Yang Q, Ren GL, Wei B, et al. Conditional knockout of TGF- $\beta$ RII /Smad2 signals protects against acute renal injury by alleviating cell necroptosis, apoptosis and inflammation. Theranostics 2019;9:8277-93.

39. Gao H, Zhang S, Hu T, et al. Omeprazole protects against cisplatin-induced nephrotoxicity by alleviating oxidative stress, inflammation, and transporter-mediated cisplatin accumulation in rats and $\mathrm{HK}-2$ cells. Chem Biol Interact 2019;297:130-40. 
40. Güntürk I, Yazici C, Köse SK, et al. The effect of $\mathrm{N}$-acetylcysteine on inflammation and oxidative stress in cisplatin-induced nephrotoxicity: a rat model Turk J Med Sci 2019;49:1789-99.

41. Iwakura T, Zhao Z, Marschner JA, et al. Dipeptidyl peptidase-4 inhibitor teneligliptin accelerates recovery from cisplatin-induced acute kidney injury by attenuating inflammation and promoting tubular regeneration. Nephrol Dial Transplant 2019;34:1669-80.

42. Wang L, Pan J, Wang T, et al. Pathological cyclic straininduced apoptosis in human periodontal ligament cells through the RhoGDI $\alpha$ /caspase-3/PARP pathway. PLoS One 2013;8:e75973.

43. Lau A, Arundine M, Sun HS, et al. Inhibition of caspasemediated apoptosis by peroxynitrite in traumatic brain injury. J Neurosci 2006;26:11540-53.

44. Lee RH, Song JM, Park MY, et al. Cisplatin-induced apoptosis by translocation of endogenous Bax in mouse collecting duct cells. Biochem Pharmacol 2001;62:1013-23.

45. Zhou Y, Xu H, Xu W, et al. Exosomes released by human umbilical cord mesenchymal stem cells protect against cisplatin-induced renal oxidative stress and apoptosis in vivo and in vitro. Stem Cell Res Ther 2013;4:34.

46. Zhang B, Ramesh G, Norbury CC, et al. Cisplatininduced nephrotoxicity is mediated by tumor necrosis factor-alpha produced by renal parenchymal cells. Kidney Int 2007;72:37-44.

47. Zirak MR, Rahimian R, Ghazi-Khansari M, et al.

Cite this article as: Yuan J, Liang X, Zhou W, Feng J, Wang Z, Shen S, Guan X, Zhao L, Deng F. TRPA1 promotes cisplatininduced nephrotoxicity through inflammation mediated by the MAPK/NF- $\kappa$ B signaling pathway. Ann Transl Med 2021;9(20):1578. doi: 10.21037/atm-21-5125
Tropisetron attenuates cisplatin-induced nephrotoxicity in mice. Eur J Pharmacol 2014;738:222-9.

48. Benedetti G, Fredriksson L, Herpers B, et al. TNF- $\alpha-$ mediated NF- $\kappa \mathrm{B}$ survival signaling impairment by cisplatin enhances JNK activation allowing synergistic apoptosis of renal proximal tubular cells. Biochem Pharmacol 2013;85:274-86.

49. Hayden MS, Ghosh S. Signaling to NF-kappaB. Genes Dev 2004;18:2195-224.

50. Zandi E, Rothwarf DM, Delhase M, et al. The IkappaB kinase complex (IKK) contains two kinase subunits, IKKalpha and IKKbeta, necessary for IkappaB phosphorylation and NF-kappaB activation. Cell 1997;91:243-52.

51. Kim HJ, Ravichandran K, Ozkok A, et al. The watersoluble triptolide derivative PG490-88 protects against cisplatin-induced acute kidney injury. J Pharmacol Exp Ther 2014;349:518-25.

52. Nowak G. Protein kinase C-alpha and ERK1/2 mediate mitochondrial dysfunction, decreases in active $\mathrm{Na}+$ transport, and cisplatin-induced apoptosis in renal cells. J Biol Chem 2002;277:43377-88.

53. Francescato HD, Costa RS, da Silva CG, et al. Treatment with a 38 MAPK inhibitor attenuates cisplatin nephrotoxicity starting after the beginning of renal damage. Life Sci 2009;84:590-7.

(English Language Editor: J. Jones) 